\title{
Plant nucleoside 5'-phosphoramidate hydrolase; simple purification from yellow lupin (Lupinus luteus) seeds and properties of homogeneous enzyme ${ }^{\star}$
}

\author{
Andrzej Guranowski ${ }^{凶}$, Anna M. Wojdyła1', Anna M. Rydzik², Janusz Stepiński² and \\ Jacek Jemielity²
}

1Department of Biochemistry and Biotechnology, Poznań University of Life Sciences, Poznań, Poland; ${ }^{2}$ Division of Biophysics, Institute of Experimental Physics, Faculty of Physics, University of Warsaw, Warszawa, Poland

\begin{abstract}
Adenosine 5'-phosphoramidate $\left(\mathrm{NH}_{2}-\mathrm{pA}\right)$ is an uncommon natural nucleotide of poorly understood biochemistry and function. We studied a plant enzyme potentially involved in the catabolism of $\mathrm{NH}_{2}-\mathrm{pA}$. A fast and simple method comprising extraction of yellow lupin (Lupinus luteus) seed-meal with a low ionic strength buffer, ammonium sulfate and acetone fractionations, removal of contaminating proteins by heat denaturation, and affinity chromatography on AMP-agarose, yielded homogenous nucleoside 5'-phosphoramidase. Mass spectrometric analysis showed that the lupin hydrolase exhibits closest similarity to Arabidopsis thaliana Hint1 protein. The substrate specificity of the lupin enzyme, in particular its ability to split the P-S bond in adenosine 5 '-phosphorothioate, is typical of known Hint1 proteins. Adenosine 5'-phosphofluoride and various derivatives of guanosine 5'-phosphoramidate were also substrates. Neither common divalent metal cations nor $10 \mathrm{mM}$ EDTA or EGTA affected the hydrolysis of $\mathrm{NH}_{2}-\mathrm{pA}$. The enzyme functions as a homodimer $(2 \times 15800 \mathrm{Da})$. At the optimum $\mathrm{pH}$ of 7.0 , the $K_{\mathrm{m}}$ for $\mathrm{NH}_{2}-\mathrm{pA}$ was $0.5 \mu \mathrm{M}$ and $\boldsymbol{k}_{\text {cat }} 0.8 \mathrm{~s}^{-1}$ (per monomer active site). The properties of the lupin nucleoside 5'-phosphoramidase are compared with those of its counterparts from other organisms.
\end{abstract}

Keywords: adenosine 5'-phosphoramidate, nucleoside 5'-phosphoramidase, purification to homogeneity, yellow lupin, Lupinus luteus

Received: 09 December, 2010; revised: 17 December, 2010; accepted: 21 December, 2010; available on-line: 14 March, 2011

\section{INTRODUCTION}

Adenosine 5'-phosphoramidate $\left(\mathrm{NH}_{2}-\mathrm{pA}\right)$ is closely linked with the metabolism of the more common adenine nucleotides. However, our knowledge of the occurrence, biochemistry and biological roles of $\mathrm{NH}_{2}-\mathrm{pA}$ is very scarce. This compound was first discovered 30 years ago among cellular nucleotides purified from the green alga Chlorella pyranoidosa (Frankhauser et al., 1981a), and proved to be a product of the following reaction catalyzed by adenylylsulfate:ammonia adenylyltransferase (EC 2.7.7.51):

$$
\mathrm{SO}_{4}^{-} \mathrm{pA}+\mathrm{NH}_{4}^{+} \rightarrow \mathrm{NH}_{2}-\mathrm{pA}+\mathrm{SO}_{4}{ }^{2-}+2 \mathrm{H}^{+} \text {. }
$$

Activity of this transferase has been reported in different organisms (Ch. pyranoidosa, Euglena gracilis, Dictyostelium discoideum, Escherichia coli, and in higher plants such as spinach and barley) and the enzyme was purified to homogeneity from Ch. pyranoidosa (Frankhauser et al., 1981b). The supposition that $\mathrm{NH}_{2}-\mathrm{pA}$ occurs in other organisms and that its concentration can be enzymatically controlled is supported by the existence of adenosine-, or generally nucleoside-5'-phosphoramidate hydrolases (EC 3.9.1.-) that catalyze cleavage of the substrate $\mathrm{P}-\mathrm{N}$ bond and liberate the corresponding 5'-NMP $(\mathrm{pN})$ and ammonia from $\mathrm{NH}_{2}-\mathrm{pA}$ or other $\mathrm{NH}_{2}$-pNs. This catabolic activity has been demonstrated in $D$. discoideum (Rossomando \& Hadjimichael, 1986), rat liver (Kuba et al., 1994), and appears to be a catalytic feature of various HIT-proteins (Bieganowski et al., 2002; Guranowski et al., 2008; 2010a; 2010b). Our preliminary studies showed that $\mathrm{NH}_{2}-\mathrm{pA}$ can be hydrolyzed by at least two enzymes from yellow lupin — dinucleoside triphosphatase/Fhit homolog protein (EC 3.6.1.29) and nucleoside phosphoramidase (Hint protein) (Guranowski et al., 2006). Here, we describe a simple method for purification of the latter enzyme to electrophoretic homogeneity and present some of its molecular and kinetic properties.

\section{MATERIALS AND METHODS}

Chemicals. Nucleotides, including adenosine 5'-phosphoramidate $\left(\mathrm{NH}_{2}-\mathrm{pA}\right)(\mathbf{1})$, adenosine 5'-phosphorothioate (S-pA) (8), AMP-agarose (cat. no. A-3019) and most of the general reagents were purchased from Sigma (St. Louis, MO, USA). Guanosine 5' phosphomorpholidate (2) was prepared according to Mukaiyama and Hashimoto (1971) from guanosine 5'-monophosphate (triethylammonium salt) and was precipitated as the sodium salt from the reaction mixture with $\mathrm{NaClO}_{4}$ in acetone with 98\% purity. Analogs 3-5 were synthesized by coupling of the appropriate diamine with nucleoside monophosphate or diphosphate (for compound 6) activated as an imidazolide derivative (Scheme 1). Reactions were conducted in aqueous media buffered to $\mathrm{pH} 8$ in order to retain nucleophilicity of the amine and at the same time to avoid degradation of the nucleotide occurring in the presence of a strong base. Reactions were monitored by HPLC and, when complete, concentrated under vacuum

\e-mail: guranow@up.poznan.pl

* Preliminary report of this study was presented at the 45th Meeting of the Polish Biochemical Society, Wisła, September 2010, Poster P6.8. Acta Biochim Polon 57 (S4): 104.

Abbreviations: HIT proteins, superfamily of proteins that contain histidine-triad sequence motif; Hint1, one of HIT proteins. 


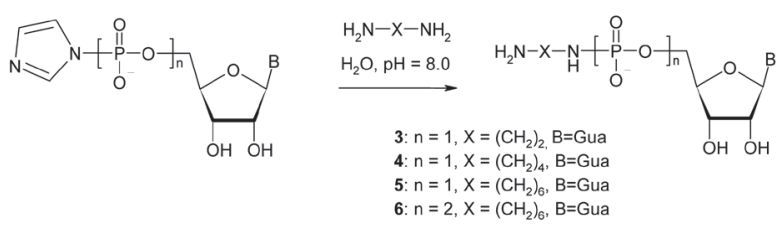

Scheme 1. Synthesis of phosphoramidate analogs (3-6) containing diamine linker

and subjected to purification by ion-exchange chromatography (DEAE Sephadex A-25).

Adenosine 5'-phosphofluoride (F-pA) (7) was synthesized as described by Wittman (1963), guanosine 5'-phosphorothioate (9) as described by Kowalska et al. (2008) and guanosine 5'-imidodiphosphate (pNHpG) (10) according to Tomasz et al. (1988). Radio-labeled adenosine$\left[8-{ }^{3} \mathrm{H}\right]-5^{\prime}$-phosphoramidate was purchased from Moravek Biochemicals (Brea, CA, USA).

Structures of the nucleotidyl derivatives used in this study are shown in Fig. 1.
Analytical methods. Orthophosphate liberated from imidodiphosphate and phosphocreatine was measured by the highly sensitive colorimetric method of Van Veldhoven and Mannaerts (1987). Protein concentration was estimated by the turbidimetric tannin method (MejbaumKatzenelenbogen, 1955). MALDI-TOF mass spectrometric analysis was performed at the proteomics facility of the Institute of Biochemistry and Biophysics, Polish Academy of Sciences (Warsaw, Poland).

Peptides that corresponded to the protein of the highest score were then analyzed in the BLAST system. Molecular mass of the native enzyme protein was estimated by gel filtration on a Sephadex G-75 superfine column. The following molecular mass standards were used: bovine serum albumin $(67 \mathrm{kDa})$, adenosine kinase from yellow lupin seeds (38 kDa) (Guranowski, 1979) and chymotrypsinogen A $(25 \mathrm{kDa})$.

Enzyme assays. Nucleoside phosphoramidase activity was measured in a reaction mixture containing 50 $\mathrm{mM}$ potassium phosphate ( $\mathrm{pH} 6.8), 1 \mathrm{mM} \mathrm{NH}_{2}-\mathrm{p}\left[{ }^{8}{ }^{3} \mathrm{H}\right]$ $\mathrm{A}$, other additions (if any), and a rate-limiting amount of the lupin enzyme. When the $K_{\mathrm{m}}$ value was estimat-

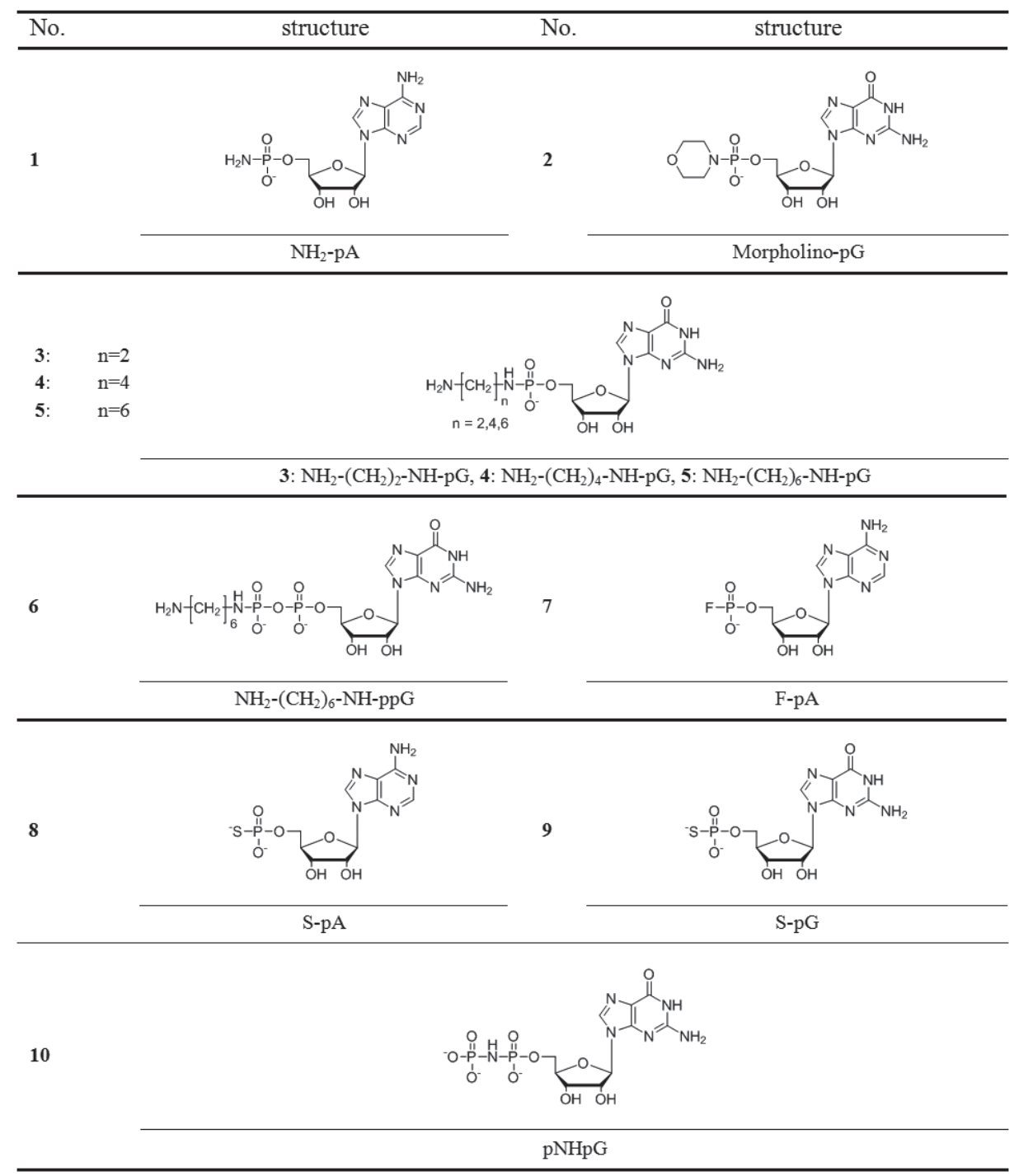


Table 1. Purification of nucleoside 5'-phosphoramidate hydrolase from yellow lupin (Lupinus luteus) seeds Purification was performed from $250 \mathrm{~g}$ of yellow lupin seed-meal.

\begin{tabular}{|c|c|c|c|c|c|c|}
\hline \multirow[t]{2}{*}{ Step } & \multicolumn{2}{|c|}{ Protein } & \multicolumn{2}{|c|}{ Activity } & \multirow{2}{*}{$\begin{array}{l}\text { Purification } \\
\text { (-fold) }\end{array}$} & \multirow{2}{*}{$\begin{array}{l}\text { Yield } \\
(\%)\end{array}$} \\
\hline & $\begin{array}{l}\text { Weight } \\
\text { (mg) }\end{array}$ & $\begin{array}{l}\text { Volume } \\
\text { (ml) }\end{array}$ & $\begin{array}{l}\text { Total } \\
(\mathrm{mU})\end{array}$ & $\begin{array}{l}\text { Specific } \\
(\mathrm{mU} / \mathrm{mg})\end{array}$ & & \\
\hline Crude extract ( $10 \mathrm{mM}$ potassium phosphate $\mathrm{pH} 6.8$ ) & 22100 & 650 & 10387 & 0.47 & 1 & 100 \\
\hline Ammonium sulfate $(0-30 \%)$ & 4050 & 75 & 2470 & 0.61 & 1.3 & 24 \\
\hline Acetone $(50-75 \%)$ & 342 & 9 & 1094 & 3.20 & 6.8 & 11 \\
\hline Heat denaturation $\left(70^{\circ} \mathrm{C}\right.$ for $\left.5 \mathrm{~min}\right)$ & 130 & 6.5 & 663 & 5.10 & 10.8 & 6.8 \\
\hline AMP-agarose (elution with $0.5 \mathrm{mM} \mathrm{NH}_{2}-\mathrm{pA}$ ) & 0.152 & 7.6 & 162 & 1065 & 2266 & 1.6 \\
\hline
\end{tabular}

ed, the substrate concentration was varied between 0.4 and $10 \mu \mathrm{M}$. At time intervals, $5 \mu \mathrm{l}$ aliquots of the reaction mixture were spotted onto an aluminum thin-layer chromatography plate precoated with silica gel containing fluorescent indicator (Merck KGaA, Darmstadt, Germany, cat. no. 1.0554.0001), standards of $\mathrm{NH}_{2}-\mathrm{pA}$ and AMP applied to the origin, and the plate was developed for $45 \mathrm{~min}$ in dioxane: $25 \%$ ammonia/water (6:1:4, by vol. solvent A). Spots of the nucleotides were visualized under short-wave UV light and those of the reaction product (AMP) cut out, immersed in scintillation cocktail, and the radioactivity was determined. The same chromatographic system was used when the enzyme was incubated with F-pA or S-pA. A different solvent, ethyl acetate/isopropanol: $25 \%$ ammonia/water (27:23:5:3, by vol. solvent B), was used for separation of guanosine liberated from the GMP product of reactions catalyzed by the lupin nucleoside phosphoramidase on different guanylylated compounds (shown in Table 2) by snake venom 5'-nucleotidase (Sigma). In the latter system the $R_{F}$ of guanosine was 0.5 while the guanylylated compounds remained at the origin. (Solvent A poorly separated the latter compounds from GMP). Under the assay conditions, conversion of $\mathrm{NH}_{2}-\mathrm{pA}$ to AMP was absolutely enzyme dependent.

\section{RESULTS}

\section{Enzyme purification}

All the purification procedures were carried out at $4{ }^{\circ} \mathrm{C}$. Meal obtained from yellow lupin seeds $(250 \mathrm{~g})$ was extracted with $650 \mathrm{ml}$ of buffer A $(10 \mathrm{mM}$ potassium phosphate, $\mathrm{pH}$ 6.8, containing $1 \mathrm{mM}$ 2-mercaptoethanol and 5\% glycerol) for 45-60 min. The debris was removed by centrifugation at $30000 \times g$ for $20 \mathrm{~min}$. The supernatant, referred to as crude extract, was brought to $30 \%$ saturation with solid ammonium sulfate. The precipitate was collected by centrifugation at $30000 \times g$ for 15 min, resolubilized in buffer $\AA$ and dialyzed against this buffer overnight. The dialysate was then centrifuged to pellet insoluble matter and to remove some fatty material that mostly floated on the top. The supernatant was subjected to fractionation with chilled $\left(-80^{\circ} \mathrm{C}\right)$ acetone. The proteins that precipitated when the acetone reached a concentration of $50 \%(\mathrm{v} / \mathrm{v})$ were discarded after centrifugation. An equal volume of acetone was then added to the resulting supernatant and proteins that precipitated at $75 \%(\mathrm{v} / \mathrm{v})$ acetone were collected by centrifugation and resolubilized in a small volume of buffer
B (50 mM potassium phosphate, $\mathrm{pH}$ 6.8, containing 1 $\mathrm{mM}$ 2-mercaptoethanol and 5\% glycerol). The sample was then divided into $0.2-\mathrm{ml}$ portions which were then subjected to heat denaturation at $70^{\circ} \mathrm{C}$ for $5 \mathrm{~min}$. The precipitated protein was removed by centrifugation $(20000 \times g$ for $10 \mathrm{~min})$ and the pooled supernatants applied to an AMP-agarose column $(1 \mathrm{~cm} \times 3 \mathrm{~cm})$ equilibrated with buffer $\mathrm{B}$. The column was washed with five volumes of buffer $\mathrm{B}$ and the nucleoside phosphoramidase desorbed from the column by affinity elution with buffer B supplemented with $0.5 \mathrm{mM}$ adenosine 5'-phosphoramidate. The ligand was removed by dialyzing the sample against buffer $B$ and the sample concentrated by dialysis against dry Sephadex G-200. The resulting fraction was stored at $-20^{\circ} \mathrm{C}$ for further analysis. The purification procedure is summarized in Table 1.

\section{Molecular properties of the enzyme}

A comparison of the results of gel filtration in nondenaturating conditions (not shown) with SDS/polyacrylamide gel electrophoresis (Fig. 2) showed that the yellow lupin nucleoside phosphoramidase functions as a homodimer of about $32 \mathrm{kDa}$. This is a value typical for many HIT-proteins. Mass spectrometric analysis performed on the homogeneous lupin protein revealed its closest similarity to the Arabidopsis thaliana Hint1 protein. This conclusion was based on the following information:

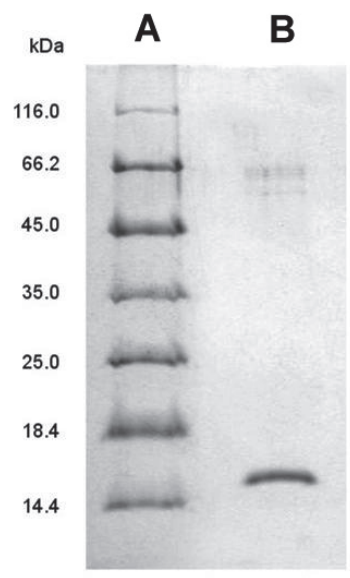

Figure 2. Electrophoresis of purified yellow lupin nucleoside 5 -phosphoramidase in the presence of SDS

Lane A, molecular mass standard proteins; lane B, $0.8 \mu \mathrm{g}$ enzyme. Two faint bands exhibiting electrophoretric mobilities corresponding to 66 and $54 \mathrm{kDa}$ are artifacts in SDS/PAGE due to 2-mercaptoethanol (Tasheva \& Dessev, 1983). 


\begin{tabular}{|c|c|c|c|c|c|c|}
\hline \multirow[t]{2}{*}{ AtHint1 } & 1 & MSHRVSILSS & HFSPASAVMA & SEKEAALAAT & PSDSPTIFDK & IISKEIPS \\
\hline & & ---------- & $--------M A$ & SE-EAALAAT & PSD-PT+FDK & II+KEIPS \\
\hline Glycine max & 1 & ----------- & $--------\mathrm{MA}$ & SETEAALAAT & PSDGPTVEDK & IINKEIPS \\
\hline \multirow[t]{2}{*}{ AtHint1 } & 51 & VFEDDKVLAF & RDITPQGPVH & ILLIPKVRDG & LTGLSKAEER & HIDILGF \\
\hline & & V+EDDKVLAAF & $\mathrm{RDI}-\mathrm{PQ}-\mathrm{P}-\mathrm{H}$ & IL+IPKVRDG & LTGLSKAEER & H-+ILGR \\
\hline Glycine max & 33 & VYEDDKVLAF & RDIDPQAPTH & ILI IPKVRDG & LTGLSKAEER & HCEILGF \\
\hline \multirow[t]{2}{*}{ AtHint1 } & 101 & TAKLVAKQEG & LAEGFRIVIN & DGPQGCQSVY & HIHVHLIGGR & QMNWPPG \\
\hline & & TAKLVAKQEG & L-+GFRIVIN & DG--G-QSVY & HIH-HLIGGR & QM-WPP- \\
\hline Glycine max & 83 & TAKLVAKQEG & LDDGFRIVIN & DGRDGGQSVY & HIHAHLIGGR & QMGWPPF \\
\hline
\end{tabular}

Figure 3. Amino-acid sequence alignment of Arabidopsis thaliana and Glycine max HIT proteins

Amino acids found in the lupin nucleoside phosphoramidase protein by mass spectrometric analysis are marked in red. Histidine triad motifs are highlighted, consensus sequence is marked in blue. Similar amino acids are marked with plus (+) and those that differ with minus (-).

The peptides obtained from the lupin nucleoside phosphoramidase were compared with known plant proteins using the MASCOT Search Program. This comparison placed an unknown protein from Glycine max (soybean), GI:255640400, as the top protein hit. Two lupin peptides matched exactly the amino-acid sequence of the soybean protein (accession: ACU20487, shown in red in the sequence alignment in Fig. 3). MASCOT additionally classified the latter protein as "related to protein kinase C interacting protein (PKCI)". PKCI and related proteins belong to the ubiquitous HIT family of hydrolases that act on alpha-phosphates of ribonucleotides. Members of this subgroup have a conserved HxHxHxx motif. PKCI has now been renamed HINT1, see for example Barbier

\begin{tabular}{|c|c|c|}
\hline No. & Compound & $\begin{array}{l}\text { Specific activity } \\
(\mu \mathrm{mol} / \mathrm{min} \times \mathrm{mg} \text { protein })\end{array}$ \\
\hline 1 & $\mathrm{NH}_{2}-\mathrm{pA}$ & 4.5 \\
\hline 2 & Morpholino-pG & 2.5 \\
\hline 3 & $\mathrm{NH}_{2}-\left(\mathrm{CH}_{2}\right)_{2}-\mathrm{NH}-\mathrm{pG}$ & 1.5 \\
\hline 4 & $\mathrm{NH}_{2}-\left(\mathrm{CH}_{2}\right)_{4}-\mathrm{NH}-\mathrm{pG}$ & 2.0 \\
\hline 5 & $\mathrm{NH}_{2}-\left(\mathrm{CH}_{2}\right)_{6}-\mathrm{NH}-\mathrm{pG}$ & 3.5 \\
\hline 6 & $\mathrm{NH}_{2}-\left(\mathrm{CH}_{2}\right)_{6}-\mathrm{NH}-\mathrm{ppG}$ & 0 \\
\hline 7 & F-pA & 1.2 \\
\hline 8 & S-pA & 0.08 \\
\hline 9 & S-pG & 0.2 \\
\hline 10 & pNHpG & 0 \\
\hline
\end{tabular}

Initial velocities of hydrolysis were measured by thin-layer chromatography. Reaction mixture $(25 \mu \mathrm{ll})$ contained $50 \mathrm{mM}$ potassium phosphate (pH 6.8), $1 \mathrm{mM}$ substrate, purified lupin enzyme $(0.05 \mu \mathrm{g}$ for compounds 1-7 and $0.3 \mu \mathrm{g}$ for compounds 8-10) and, in the case of compounds 2-6, 0.1 unit of snake venom 5'-nucleotidase. Reaction was carried out at $30^{\circ} \mathrm{C}$. Aliquots of $3-\mu \mathrm{l}$ were withdrawn at appropriate times and spotted on the origin of thin-layer plate. Separation of potential product of reaction(s) (AMP in the case of $\mathbf{1}$ and $\mathbf{8}$, GMP in the case of 9 and guanosine in the case of 2-5) from substrate was performed as described in Materials and Methods after development of the plate in solvent A or B. Evaluation of enzyme activity was based on densitometric measurements carried out with a G-Box documentation system. Specific activity values are means of three independent measurements; standard errors did not exceed $15 \%$.
\& Wang (2009). Finally, the BLAST search revealed that the lupin and soybean proteins share their amino-acid sequences with the protein kinase $\mathrm{C}$ inhibitor-like protein from $A$. thaliana (GI:7594527, accession CAB88052) which has also been identified as AtHint1, GenBank entry AT3G56490 (Guranowski et al., 2010a).

Based on the UV absorbance of the enzyme solution and on protein concentration estimated by the turbidimetric tannin method, which relates the OD at $600 \mathrm{~nm}$ to the protein mass (the light scattering caused by the protein-tannin particles is not affected by amino-acid composition), the calculated $A_{280}$ of a $1 \%$ solution was 10.

\section{Kinetic parameters}

The optimum $\mathrm{pH}$ estimated in $50 \mathrm{mM}$ potassium phosphate, Mes/KOH and Hepes/KOH buffers was around 7. The hydrolytic cleavage of the $\mathrm{P}-\mathrm{N}$ bond in $\mathrm{NH}_{2}$ - $\mathrm{pA}$, measured in $50 \mathrm{mM}$ potassium phosphate $(\mathrm{pH}$ 6.8), followed Michaelis-Menten kinetics. The apparent $K_{\mathrm{m}}$ value calculated from an Eadie-Hofstee plot ( $v$ versus $v /[\mathrm{S}])$ was $0.5 \mu \mathrm{M}$ and the $k_{\text {cat }}$ calculated per monomer active site was $0.8 \mathrm{~s}^{-1}$. Thus the substrate specificity constant $\left(k_{\mathrm{cat}} / K_{\mathrm{m}}\right)$ was $1.6 \times 10^{6} \mathrm{M}^{-1} \mathrm{~s}^{-1}$. The reaction did not depend on divalent metal cations. Furthermore, neither EDTA nor EGTA up to $10 \mathrm{mM}$ affected the hydrolysis of $\mathrm{NH}_{2}-\mathrm{pA}$.

\section{Substrate specificity}

Different derivatives of AMP and a set of guanosine 5'-phosphoramidates were tested as potential substrates. Of the former, the lupin phosphoramidase recognized F-pA and S-pA as substrates in addition to $\mathrm{NH}_{2}-\mathrm{pA}$. Neither App-pA, a substrate of Fhit proteins, nor $\mathrm{SO}_{4}^{-}$ $\mathrm{pA}$, which appears to be readily recognized by many HIT proteins, though poorly by rabbit Hint and yeast Hnt1, were hydrolyzed by the lupin enzyme. As shown in Table 2, of all the compounds studied, $\mathrm{NH}_{2}-\mathrm{pA}$ was the best substrate. Among three aminoalkyl derivatives of guanosine phosphoramidate the highest rate of GMP release was observed for the compound with the longest aminoalkyl chain (the aminohexyl derivative). Of two nucleoside 5'-phosphorothioates, the P-S bond cleavage was catalyzed 2.5-fold faster in S-pG than in S-pA. The same preference for liberation of hydrogen sulfide from different nucleoside 5'-phosphoramidates was also ob- 
served for rabbit Hint1 (Ozga et al., 2010). Two other compounds with $\mathrm{P}-\mathrm{N}$ bonds, phosphocreatine and imidodiphosphate, were resistant to the lupin enzyme.

\section{DISCUSSION}

\section{Purification of yellow lupin nucleoside 5'-phosphoramidase}

This study concerns the first nucleoside 5'-phosphoramidase to be purified to homogeneity from a higher plant. Each step described in the purification procedure was based on numerous pilot experiments, the results of which are discussed below. Previously in this laboratory, buffer salt concentration was shown to markedly affect the extraction of enzymes from plant tissues. For example, adenosine nucleosidase from barley leaves was effectively extracted only at high ionic strength $(50 \mathrm{mM}$ Tris/HCl containing $1 \mathrm{M} \mathrm{KCl}$ ) (Guranowski \& Schneider, 1977). Also the activities of some aminoacyl-tRNA synthetases extracted from the meal of yellow lupin seeds increased with the phosphate buffer concentration (Jakubowski \& Pawełkiewicz, 1974). Generally, a higher buffer salt concentration leads to a higher protein concentration in the extract. Therefore it is worth checking whether the protein under study is affected by this parameter in order to increase its yield and to minimize the amount of contaminating proteins which can be hard to eliminate in subsequent purification steps.

Experiments on ammonium sulfate fractionation showed that the highest activity of the nucleoside phosphoramidase was in the protein fraction that precipitated at $30 \%$ saturation. At this stage another enzyme that can hydrolyze $\mathrm{NH}_{2}-\mathrm{pA}$, dinucleoside triphosphatase (a Fhit protein homolog), is eliminated (Guranowski et al., 2006; 2008); as shown previously, it precipitates at 50-70\% ammonium sulfate saturation (Jakubowski \& Guranowski, 1983; Guranowski et al., 1996). This explains, at least in part, the decrease of total activity and poor yield at this purification step (Table 1).

Before deciding to apply acetone fractionation, ionexchange chromatography was tried to further purify the enzyme obtained at $30 \%$ saturation of the crude extract with ammonium sulfate. However, this took several days because fatty material present in the applied dialysate clogged the column. Fortunately, chilled acetone used at a proportion of $1: 1$ by volume precipitated many of the contaminating proteins and removed the fatty material. The enzyme protein precipitated without losing activity when the acetone concentration reached $75 \%(\mathrm{v} / \mathrm{v})$.

The next step, removal of contaminating proteins by heat denaturation, was possible as a result of the remarkable thermostability of the phosphoramidase. This property was first noticed when we tried to estimate enzyme activity by a colorimetric assay which measures orthophosphate concentration. Initial attempts to terminate the reaction by heating the mixture containing $\mathrm{NH}_{2}-\mathrm{pA}$ at $96{ }^{\circ} \mathrm{C}$ for $5 \mathrm{~min}$ and then adding alkaline phosphatase to release orthophosphate from AMP (or any NMP substrate produced by the nucleoside phosphoramidase) failed to give reproducible results because of the unexpectedly high thermostability of the phosphoramidase.

The most effective purification step was affinity elution from AMP-agarose. In contrast to rabbit Hint and yeast Hnt1, both of which exhibit nucleoside phosphoramidase activity and which can be eluted from the same type of affinity column with adenosine (Bieganowski et al., 2002), their yellow lupin counterpart did not elute with adenosine but did so readily in the presence of $0.5 \mathrm{mM} \mathrm{NH}_{2}$-pA. The procedure is simple and fast. Although the yield of the activity is low, a preparation of homogeneous nucleoside phosphoramidase can be obtained in 2 to 3 days.

\section{Enzyme properties}

The yellow lupin enzyme exhibits many similarities to its rat liver counterpart (Kuba et al., 1994) and to the recombinant proteins from rabbit (rHint1) (Bieganowski et al., 2002; Ozga et al., 2010), yeast (Hnt1) (Bieganowski et al., 2002) and $A$. thaliana (AtHint1) (Guranowski et al., 2010b). Among these are amino-acid sequence similarity and substrate specificity. All these enzymes function as homodimers, with the monomer of the lupin enzyme $(15.8 \mathrm{kDa})$ being slightly larger than that from rat liver (14 kDa) (Kuba et al., 1994). The enzyme preferentially catalyzes hydrolysis of the $\mathrm{P}-\mathrm{N}$ bond in nucleoside 5 '-monophosphoramidates and their derivatives but is not able to split the $\mathrm{P}-\mathrm{N}$ bond in nucleoside diphosphoramidates such as pNHpG (10) or $\mathrm{NH}_{2}\left(\mathrm{CH}_{2}\right)_{6} \mathrm{NHPpG}$ (6). It is also active towards some other nucleotides with P-F or P-S bonds (compounds 7-9) but not towards anhydrides such as $\mathrm{SO}_{4}-\mathrm{pA}$ and App-pA. The P-F bond in F-pA and the $\mathrm{P}-\mathrm{S}$ bond in $\mathrm{S}-\mathrm{pA}$ were respectively cleaved at rates 4 - and 56-fold lower than the $\mathrm{P}-\mathrm{N}$ bond in the preferred substrate $\mathrm{NH}_{2}-\mathrm{pA}$. In contrast to the lupin enzyme, rabbit Hint1 and yeast Hnt1 catalyzed liberation of AMP from $\mathrm{SO}_{4}$-pA but at respective rates 23and 260-fold lower than the rate of hydrolysis of $\mathrm{NH}_{2}-$ pA (Bieganowski et al., 2002). The $\mathrm{pH}$ optimum estimated for the rat liver enzyme (Kuba et al., 1994) and the kinetic parameters estimated for the pure yellow lupin enzyme are in the same range as those estimated for the recombinant rabbit and yeast counterparts $-K_{\mathrm{m}}$ values below $10^{-6} \mathrm{M}$ for $\mathrm{NH}_{2}-\mathrm{pA}$ and $k_{\text {cat }}$ values below $1 \mathrm{~s}^{-1}$. Thus the substrate specificity expressed as $k_{\text {cat }} / K_{m}$ is $1.6 \times 10^{6} \mathrm{M}^{-1} \mathrm{~s}^{-1}$ for the lupin enzyme, $2.9 \times 10^{6} \mathrm{M}^{-1} \mathrm{~s}^{-1}$ for the rabbit and $1 \times 10^{6} \mathrm{M}^{-1} \mathrm{~s}^{-1}$ for the yeast Hint proteins. There is some discrepancy concerning the effects of divalent metal cations. In our studies neither the AtHint1 (Guranowski et al., 2010b) nor the yellow lupin enzyme described here required these cofactors. However, in the absence of $\mathrm{MgCl}_{2}$, rabbit Hint and yeast Hnt1 were reported to show only $10 \%$ of the activities exhibited at $0.5 \mathrm{mM} \mathrm{MgCl}_{2}$ (Bieganowski et al., 2002).

\section{Acknowledgement}

We thank Professor Alexander McLennan (University of Liverpool, UK) for critical reading of the manuscript, valuable suggestions and linguistic help in preparation of this paper.

This work was supported by the Ministry of Science and Higher Education (grant PBZ-MNiSW-07/I/2007).

\section{REFERENCES}

Barbier E, Wang JB (2009) Anti-depressant anxiolytic like behaviors in PKCI/HINT 1 knockout mice associated with elevated plasma corticosterone level. BMC Neurosience 10: 132: 1-14.

Bieganowski P, Garrison PN, Hodawadekar SC, Faye G, Barnes LD, Brenner C (2002) Adenosine monophosphoramidase activity of Hint and Hnt1 supports function of Kin28, Cc11, and Tfb3. J Biol Chem 277: 10852-10860.

Frankhauser H, Berkowitz GA, Schiff JA (1981a) A nucleotide with the properties of adenosine 5'-phosphoramidate from Chlorella cells. Biochem Biophys Res Commun 101: 524-532.

Frankhauser H, Schiff JA, Graber LJ (1981b) Purification and properties of adenylyl sulphate:ammonia adenylyltransferase from Chlorella 
catalyzing the formation of adenosine phosphoramidate from adenosine 5'-phosphosulphate and ammonia. Biochem J 195: 545-560.

Guranowski A (1979) Plant adenosine kinase: purification and some properties of the enzyme from Lupinus luteus seeds. Arch Biochem Biophys 196: 220-226.

Guranowski A, Schneider Z (1977) Purification and characterization of adenosine nucleosidase from barley leaves. Biochim Biophys Acta 482: $145-158$.

Guranowski A, Starzynska E, Bojarska E, Stepinski J, Darzynkiewicz E (1996) Dinucleoside 5',5"'- $P^{1}, P^{3}$-triphosphate hydrolase from yellow lupin (Lupinus luteus) seeds: purification to homogeneity and hydrolysis of mRNA 5'-cap analogs. Protein Expression Purif 8: 416-422.

Guranowski A, Wojdyła AM, Pietrowska-Borek M, Bieganowski P, Khurs EN, Cliff MJ, Blackburn GM, Błaziak D, Stec, W J (2008) Fhit proteins can also recognize substrates other than dinucleoside polyphosphates. FEBS Lett 582: 3152-3158.

Guranowski A, Bieganowski P, Baraniak J, Rydzik A, Stępiński J, Jemielity J (2006) Catabolism of nucleoside phosphoramidates in higher plants can be controlled by nucleoside phosphoramidase (Hint protein) and dinucleoside triphosphatase (Fhit protein). Acta Biochim Pol 53 (Suppl 1): 183-184.

Guranowski A, Wojdyła AM, Zimny J, Wypijewska A, Kowalska J, Jemielity J, Davis RE, Bieganowski P (2010a) Dual activity of certain HIT-proteins: $A$. thaliana Hint 4 and $C$. elegans DcpS act on adenosine 5'-phosphosulfate as hydrolases (forming AMP) and as phosphorylases (forming ADP). FEBS Lett 584: 93-98.

Guranowski A, Wojdyła AM, Zimny J, Wypijewska A, Kowalska J, Łukaszewicz M, Jemielity J, Darżynkiewicz E, Jagiełło A, Bieganowski P (2010b) Recognition of different nucleotidyl-derivatives as substrates of reactions catalyzed by various HIT-proteins. New J Chem 34: 888-893.

Jakubowski H, Pawelkiewicz J (1974) Valyl-tRNA synthetase of yellow lupin seeds. Purification and some properties. Acta Biochim Pol 21: 271-282.

Jakubowski H, Guranowski A (1983) Enzymes hydrolyzing ApppA and/or AppppA in higher plants. Purification and some properties of diadenosine triphosphatase, diadenosine tetraphosphatase, and phosphodiesterase from yellow lupin (Lupinus lutesu) seeds. J Biol Chem 258: 9982-9989.

Kowalska J, Lewdorowicz M, Zuberek J, Grudzien-Nogalska E, Bojarska E, Stepinski J, Rhoads RE, Darzynkiewicz E, Davis RE, Jemielity J (2008) Synthesis and characterization of mRNA cap analogs containing phosphorothioate substitutions that bind tightly to eIF4E and are resistant to the decapping pyrophosphatase DcpS. RNA 14: 1119-1131.

Kuba M, Okazaki T, Ohmori H, Kumon A (1994) Nucleoside monophosphoramidate hydrolase from rat liver: purification and characterization. Int J Biochem 26: 235-245.

Mejbaum-Katzenelenbogen W (1955) Turbidymetryczna mikrometoda oznaczania białek tanina. Acta Biochim Pol 2: 279-296 (in Polish).

Mukaiyama T, Hashimoto M (1971) Phosphorylation by oxidationreduction condensation. Preparation of active phosphorylating reagents. Bul Chem Soc Japan 44: 2284.

Ozga M, Dolot R, Janicka M, Kaczmarek R, Krakowiak A (2010) Histidine triad nucleotide-binding protein 1 (Hint-1) phosphoramidase transforms nucleoside 5'-O-phosphorothioates to nucleoside 5'-phosphates. J Biol Chem 285: 40809-40818.

Rossomando EF, Hadjimichael J (1986) Characterization and cAMP

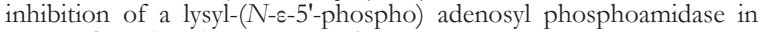
Dictyostelium discoideum. Int J Biochem 18: 481-484.

Tasheva B, Dessev G (1983) Artifacts in sodium dodecyl sulfate-polyacrylamide gel electrophoresis due to 2-mercaptoethanol. Anal Biochem 128: 98-102.

Tomasz J, Vaghefi MM, Ratsep PC, Willis RC, Robins RK (1988) Nucleoside imidodiphosphates synthesis and biological activities. Nucleic Acids Res 16: 8645-8664.

Van Veldhoven PP, Mannaerts GP (1987) Inorganic and organic phosphate measurements in the nanomolar range. Anal Biochem 161: 45-48.

Wittman R (1963) Die Reaction der Phosphorsäuren mit 2,4-Dinitro-fluorobenzol. I: Eine neue Synthese von Monofluorophosphorsäurenmonoestern. Chem Ber 96: 771-779. 